\title{
The Impact of External Shari'ah Auditing on the Efficiency of Jordanian Islamic Banks Performance
}

\author{
Mohammad Falah Al Samara ${ }^{1}$, Osama Abdulmunin Al Ali ${ }^{1}$ \& Jamal Hassan AL Afeef ${ }^{1}$ \\ ${ }^{1}$ Accounting Department, Jadara University, Jordan \\ Correspondence: Mohammad Falah Al Samara, Accounting Department, Jadara University, Jordan. E-mail: \\ samara@jadara.edu.jo
}

Received: March 13, 2019

Accepted: April 20, 2019

Online Published: April 25, 2019

doi:10.5539/ijbm.v14n5p183

URL: https://doi.org/10.5539/ijbm.v14n5p183

\begin{abstract}
This study aimed to explore the impact of external Shari'ah auditing on the efficiency of Jordanian Islamic banks performance. This study has used SEM to analyze collected data from auditors and employees in Islamic banks in Jordan. This study has used a questionnaire to explore the perception of external Shari'ah audit of Islamic banks in Jordan, then the model estimated, after dropping the variables show good model fit indicators. this study examined the effect of Shari'ah audit through eight construct and found that, seven constructs significantly affect Islamic banks performance, i.e. planning, risk assessment, materiality assessment, sampling, internal controls-testing, evaluation of observations and Shari'ah non-compliances, using the work of relevant internal functions leads to better efficiency of performances in Islamic banks, except internal control-assessment. This study has practical and significance contribution for Islamic banks about of importance external Shari'ah auditing on its efficiency.
\end{abstract}

Keywords: external Shari'ah auditing, Islamic Banks, SEM, Jordan

\section{Introduction}

External Shari'ah Audit is an external control tool designed to form an independent opinion by the Shari'ah Supervisory Board regarding the commitment of the banks management to which extent employees and departments comply with principles of Islamic Shari'ah and the regulations and recommendations of the Fatwa Board and the organizations regulating the profession, and to report thereon to the General Assembly through an independent auditor. Accounting and Auditing Organization for Islamic Financial Institutions "AAOIFI", 2018; Al-Khulaifi, 2004; Mohammad, 2009)

External Shari'ah auditing is one of the most important indicators of the credibility of Islamic banks and the extent to which their applications are compatible. However, in the absence or weakness of the function of Shari'ah auditing, Islamic banks become mere slogans that lack credibility.

External Shari'ah Auditing Standard number six provides special process to ensure the quality of the Islamic banks commitment with the principles of Shariah (AAOIFI, 2018)

The Shari'ah standards provides a guide for professionals in charge of external Shari'ah audits of Islamic banks in line with international best practices as an important part of the governance of the Islamic financial industry, which in turn enhances the confidence of the owners' interests.

The importance of Shari'ah auditing is increased consciousness in Islamic institutions that each institution should contribute towards achieving and complying with the objectives of the Islamic law (Shahul and Yaya, 2005).

The general objective of this study is to provide knowledge, better understanding and insights into Islamic practices for evaluation efficiency of Islamic banks performance in accordance with Shari'ah standard number six. Thus, we examined the effect of external Shari'ah auditing on Islamic Banks performance in Jordan, specially, in a very important and fast-growing sector; such as Islamic banks in Jordan.

\section{Literature Review}

Shari'ah Standard number six is issued to provide an advisory guide for professionals engaged in external Shari'ah auditing of Islamic financial institutions, it was issued in line with international best practices as an important part of the governance of the Islamic financial industry, which in turn enhances stakeholder confidence 
and integrate practices in relation with the processes and quality improvement and harmonize global practices of external auditing.

One of the unique tasks played by the external auditor, besides performing the financial statements audit, is to test Shari'ah compliance in Islamic banks. The audit process include a structured, documented plan involving a series of steps beginning with planning the audit and ending with issued the external audit report as to make sure the financial statements are prepared in accordance with the fatwa guidelines were issued by the Shari'ah Supervisory Board (SSB), the accounting standards of the AAOIFI, and relevant national accounting standards and practices in the country in which auditor operates (Arwani, 2018).

(Kurd, 2010) claimed that financial performance and efficiency have to be measured regularly, hence performance measurement is considered as a major requirement to maintain the growing and sustainability of the Islamic banks (Qasim, Mohamad and Ibrahim, 2017).

The efficiency and profitability of Islamic banks through globalization phenomenon has put Islamic banks in competition with traditional banks in well-developed financial markets, (Bashir, 2001), so the performance evaluation of Islamic banks is especially important due to type of clients of Islamic banks.

Most of the prior studies highlighted the external Shari'ah audit and the Shari'ah Auditing Standard number six with the Islamic banks performance in general, while this study addresses the relationship between that standards and the Islamic banks performance, through addressing the most main requirements performed by the external Shari'ah auditor i.e. planning, Risk assessment, Materiality assessment, Sampling, Internal control assessment, Internal controls-testing, Evaluation of observations and Shari'ah non-compliances and Using the work of relevant internal functions.

\section{External Shari'ah Auditing}

\section{- Planning}

Shafii, Salleh and Shahwan (2010) argued that effective planning, as procedure by auditors is necessary to determine whether reasonable assurance to achievement of Shariah compliance objectives. So auditors will start plan each review assignment and the documentation (Haniffa, 2010).

\section{- Risk assessment}

Rahman, Alsmady, Ibrahim and Muhammad (2014) claimed that usually the risk assessment is considered as one of the most challenging tasks. Comprehensive and systematic procedures of risk identification are essential in ensuring the accuracy of risk assessment (Chapman, 1998). The principles of the bank's risk management policies it's ensure risk assessment and monitoring is strictly independent from the business lines (Swartz, 2013).

\section{- Materiality assessment}

AAOIFI defines the materiality of information as follows: "Information is material if its omission or misstatement could influence the decisions that users make on the basis of an IFI's financial information" AAOIFI, 2011).

In Islamic perspective, materiality considers any information that will indicate justice in valuation and implement of the rights of Allah, society and individuals concerned (Haniffa, Hudaib and Mirza, 2004).

Information either qualitatively or quantitatively that is materiality should be presented for Islamic Banks and Financial Institutions, that materiality and adequate disclosure are interrelated and relate to the characteristic of relevance and reliability(AAOIFI, 2011).

\section{- Sampling}

The external Shari'ah auditor should be used the statistical methods and judgment with consider to risk of Shari'ah non-compliance. The sample size should be increased adequately (Merah, 2017).

\section{- Internal control-assessment}

During the process of planning and implementing the related process, the external auditor should be apply sufficient procedures to obtain a description of the control risks and then evaluate them. Internal control procedures reduce process diversity to lead more predictable outcomes (Sultana and Haque, 2011). Internal control system is important for Islamic banks to achieve their objectives.

\section{- Internal controls-testing}

Internal control effectiveness defined as objective to ensure a sound and effective appropriate internal control system of Shari'ah compliance (Khalid \& Sarea, 2018; Rahman, 2011). The audit program and audit plan should be at least have specific procedures to test the Islamic banks internal controls (Ginena \& Hamid, 2015). 


\section{-. Evaluation of observations and Shari'ah non-compliances}

The Shari'ah Committee playing as supervisor role on Shari'ah issues related to the institution's operations and activities, this should be achieved by the Shari'ah review and the Shariah audit functions, usually Shari'ah review reports and the Shari'ah audit observations should enable the Shari'ah Committee to spotlight matters that require corrective measures (Ginena \& Hamid, 2015).

\section{- Using the work of relevant internal functions}

Internal functions are the internal Shari'ah auditor, Shari'ah review and the report of Shari'ah observers, additional to evaluate the reliability and level of independence. The basis of the evaluation is the statement of relative independence from management, the receipt of the reports issued and then the review during the period of the related process. International financial institutes that have internal Shari'ah audit are more effective and efficient than those do not have such functions to mitigate fraud in their institutes, then an effective internal Shari'ah auditor is the one who aid international financial institutes in achieve their objectives (Khalid \& Sarea, 2018).

\section{Methodology}

We used to analyze SEM by Analysis of Moments Structure (AMOS) and software SPSS to test another processes.

\subsection{Sampling}

This study collected data from two sources; first, it contacted Islamic banks auditors; second, it contacted employees in Islamic banks in Jordan.

This study has developed a questionnaire to explore the perception of external Shari'ah audit of Islamic banks in Jordan we initially started to measure the constructs based on the analysis of prior studies in order to ensure content validity, then, the design is enhanced by the insight gained from discussions with experts, academics and professionals,

The survey was of two parts, the first part consisted of 54 questions, related on latent factors, and the second part consisted of 5 questions, related to the demographic factors. The individuals who answered this survey were auditors and Islamic banks employees in Jordan (35 banks employee and 72 auditors). 119 surveys were collected, while only 107 questionnaires valid. The variables were measured by a 5-Likert scaled as 1 (strongly disagree) to 5 (strongly agree). Hair, Anderson and Tatham (1998) recommended that 100 is the minimum sample size to ensure the appropriate use of maximum likelihood estimation in SEM.

\subsection{Hypotheses Statement}

Eight testable hypotheses were summarizing as proposed. The following hypotheses were generated for this study:

$\mathrm{H}_{1}$. Planning is significantly affects efficiency of Islamic banks performance.

$\mathrm{H}_{2}$. Risk assessment is significantly affects efficiency of Islamic banks performance

$H_{3}$. Materiality assessment is significantly affects efficiency of Islamic banks performance.

$H_{4}$. Sampling is significantly affects efficiency of Islamic banks performance.

$H_{5}$. Internal control-assessment is significantly affects efficiency of Islamic banks performance.

$H_{6}$. Internal controls-testing is significantly affects efficiency of Islamic banks performance.

$H_{7}$. Evaluation of observations and Shari'ah non-compliances is significantly affects efficiency of Islamic banks performance.

$H_{8}$. Using the work of relevant internal functions are significantly affects efficiency of Islamic banks performance.

The conceptual framework proposed for this study is shown in Figure (1). It is develop from the literature review related of Shariah Standard number six is issued from AAOIFI.

\section{Result}

Structural equation modeling (SEM) was used to analyze the model. At the beginning, the measurement study model was examined in order to instrument validation, followed by an analysis of the structural model for testing all hypotheses, then, the measurement models with all 54 items were evaluated using confirmatory factor 
analysis. Evaluating the total measurement model showed that model fit indicators did not have acceptable values. Therefore, the model needed modifications.

Therefore, the some variables dropped from the model. The results of the model estimate, after dropping the variables show good model fit indicators.

Thus, confirmatory factor analysis of External Shari'ah Audit of Islamic Banks (54 items), after having done the confirmatory factor analysis the results showed that (EP1, EP3, EP8, EP10, EP11, EP12, PL5, RA1, RA3, MA2, MA4, SA2, SA4, IA1, IA2, IA6, IT3, EO5, EO6 and UF3) were dropped, while the other remaining items (EP2, EP4, EP5, EP6, EP7, EP9, PL1, PL2, PL3, PL4, RA2, RA4, RA5, MA1, MA3, MA5, SA1, SA3, SA5, IA3, IA4, IA5, IT1, IT2, IT4, IT5, EO1, EO2, EO3, EO4, UF1, UF2, UF4and UF5) were analyzed and showed that all the items have a factor loading of more than .50 (Hair, Black, Babin, Anderson, \& Tatham, 2010).

\subsection{Normality Test}

Normality test was carried to test whether data obtained is normally distributed based on skewness and kurtosis. George and Mallery (2010) suggested that the acceptable range for skewness and kurtosis is +2 , according to Kline (2015) an absolute value greater than 3 is considered skewed, while for kurtosis value should be within the range of \pm 3 (Kline, 2005).

Table 1. Assessment of normality

\begin{tabular}{|c|c|c|c|c|}
\hline Construct & Skewness & c.r. & Kurtosis & c.r. \\
\hline EP2 & -0.383 & -1.618 & -0.154 & -0.326 \\
\hline EP4 & -1.012 & -4.274 & 2.789 & 5.908 \\
\hline EP5 & -0.941 & -3.972 & 1.067 & 2.252 \\
\hline EP6 & -0.987 & -4.167 & 1.437 & 2.844 \\
\hline EP7 & -0.580 & -2.450 & 0.593 & 1.252 \\
\hline EP9 & -0.77 & -3.270 & 0.971 & 2.050 \\
\hline PL1 & -1.003 & -4.353 & 0.977 & 2.062 \\
\hline PL2 & -1.060 & -4.477 & 1.632 & 3.445 \\
\hline PL3 & -0.668 & -2.822 & 0.563 & 1.190 \\
\hline PL4 & -0.601 & -2.538 & 0.957 & 2.020 \\
\hline RA2 & -0.421 & -1.776 & 0.372 & 0.786 \\
\hline RA4 & -0.579 & -2.446 & 0.073 & 0.154 \\
\hline RA5 & -0.646 & -2.728 & 0.458 & 0.967 \\
\hline MA1 & -0.815 & -3.444 & 0.479 & 1.012 \\
\hline MA3 & -1.091 & -4.609 & 0.757 & 1.597 \\
\hline MA5 & -1.009 & -4.263 & 0.990 & 2.091 \\
\hline SA1 & -0.384 & -1.623 & 0.165 & 0.348 \\
\hline SA3 & -0.389 & -1.643 & 0.280 & 0.591 \\
\hline SA5 & -0.438 & -1.849 & 0.153 & 0.324 \\
\hline IA3 & -0.058 & -0.243 & -0.469 & -0.989 \\
\hline IA4 & -0.372 & -1.571 & -0.740 & -1.562 \\
\hline IA5 & -0.348 & -1.496 & 1.130 & 2.386 \\
\hline IT1 & -0.551 & -2.327 & -0.112 & -0.236 \\
\hline IT2 & -0.229 & -0.968 & -0.532 & -1.124 \\
\hline IT4 & 0.047 & 0.200 & -0.821 & -1.733 \\
\hline IT5 & -0.176 & -0.745 & -0.487 & -1.029 \\
\hline EO1 & -0.909 & -3.837 & 0.981 & 2.070 \\
\hline EO2 & -0.838 & -3.539 & 1.704 & 3.597 \\
\hline EO3 & -0.614 & -2.592 & 0.165 & 0.349 \\
\hline EO4 & -1.044 & -4.409 & 1.686 & 3.560 \\
\hline UF1 & -0.497 & -2.097 & 0.884 & 1.866 \\
\hline UF2 & -0.499 & -2.108 & 0.552 & 1.166 \\
\hline UF4 & -0.694 & -2.932 & 1.687 & 3.563 \\
\hline UF5 & -0.629 & -2.658 & 0.975 & 2.058 \\
\hline
\end{tabular}


Table 1 shows maximum value for skewness is 0.47 , and minimum value -1.091 , while maximum value for kurtosis is 2.789 , and minimum value -0.821 , thus, it is assumed that variables are normally distributed.

\subsection{Reliability and Convergent Validity}

Testing reliability and validity of constructed model was done by using Cronbach's alpha value, composite reliability (CR) and average variance extracted (AVE).

Cronbach's alpha value should be more than 0.7 to represent a good reliability (Hair et al., (2010); Khalid and Amjad, 2012; Berthoud, 2000; Cronbach, 1971), as per Hair et al., (2010) the AVE represents should be more than 0.5 to be considered valid.

Table (2) shows that the model fulfills all the conditions for reliability and validity test. In additional VIF test was less than 3, which the model proved to be free of multicollinearity, or as correlation less than 0.8 , the model proved to be free multicollinearity (Hair et al., 2010), where the max correlation between the variables was 0.775 .

To check the adequacy of sample for factor analysis, for KMO, the value should be higher than .5 in order to accept for factor analysis, and the result for Bartlett's test has to be significant in order to accept that the variables are correlated.

Table 2. Reliability \& validity

\begin{tabular}{llll}
\hline Construct & Cronbach's Alpha & AVE & CR \\
\hline Efficiency of Islamic Banks performance & 0.891 & 0.611 & 0.904 \\
Planning & 0.901 & 0.738 & 0.919 \\
Risk assessment & 0.890 & 0.736 & 0.893 \\
Materiality assessment & 0.908 & 0.770 & 0.909 \\
Sampling & 0.933 & 0.763 & 0.906 \\
Internal control-assessment & 0.888 & 0.745 & 0.897 \\
Internal controls-testing & 0.917 & 0.721 & 0.912 \\
Evaluation of observations and Shari'ah non-compliances & 0.855 & 0.576 & 0.844 \\
Using the work of relevant internal functions & 0.878 & 0.666 & 0.888 \\
\hline
\end{tabular}

Note: Maximum Likelihood analysis with Kaiser normalization, varimax rotation $K M O=0.856$; Bartlett's test of sphericity $=\chi 2=4665.989$ df $1431(p=0.000)($ SPSS 22.0).

\subsection{Structural Model}

Structural model was developed to ensure that all instruments are fit for the model, to test hypotheses for casual effect to obtain the coefficient of $\mathrm{R}^{2}$. The paths of causality between the underlying exogenous and endogenous constructs were specified in the structural model. The direct effect is that goes directly from exogenous construct to endogenous construct.

Endogenous constructs include efficiency of Islamic banks performance, whereas exogenous construct included external Shari'ah audit (i.e Planning, Risk assessment, Materiality assessment, Sampling, Internal control-assessment, Internal controls-testing, Evaluation of observations and Shari'ah non-compliances, using the work of relevant internal functions)

The hypothesized structural model was specified by including the constructs after its validation, and was tested in the next step, including eight paths representing the hypotheses $\left(\mathrm{H}_{1}, \mathrm{H}_{2}, \mathrm{H}_{3}, \mathrm{H}_{4}, \mathrm{H}_{5}, \mathrm{H}_{6}, \mathrm{H}_{7}\right.$ and $\left.\mathrm{H}_{8}\right)$. To test the hypotheses, we follow recommend five fitness indexes for measurement. The absolute fit indices, incremental fit indices and parsimonious fit indices. Values of absolute fit indices require significant of $\chi 2$ more than 0.05 and RMSEA less than 0.08 and RMR or SRMR less than 0.08. Incremental fit indices aforementioned TLI more than 0.95, CFI more than 0.95. Furthermore, Parsimonious fit recommended retain $\chi 2$ df less than 3 (Hair et al., 2010; Kline, 2010; Chau \& Hu, 2001; Tabachnick \& Fidell, 2007; Hu \& Bentler, 1999; Hooper, Coughlan, \& Mullen, 2008)

The process resulted in deleting (20) items without effecting the content of Shari'ah audit for Islamic bank implementation. The remaining constructs and items are still significant in the modified model to test the Shari'ah audit for Islamic bank implementation construct indicates are correlated. The modified measurement model as shown in Figure (1), was found to be acceptably fit the data and represented with (34) items. The 
chi-square $(\chi 2)$ was 524.774 with degrees of freedom $(\mathrm{df})$ of 483 and $\mathrm{p}$ value 0.092 , the $\mathrm{TLI}=0.983$, CFI $=$ $0.985, \mathrm{RMSEA}=0.029, \mathrm{RMR}=0.027, \mathrm{SRMR}=0.053$ and $(\chi 2 / \mathrm{df})=1.086$, all the values are in the recommended range for indices for the measurement model. The standardized factor loadings are all above 0.70 and no large standardized residuals covariance. Therefore, the results support measurement model of Shari'ah audit for Islamic bank implementation.

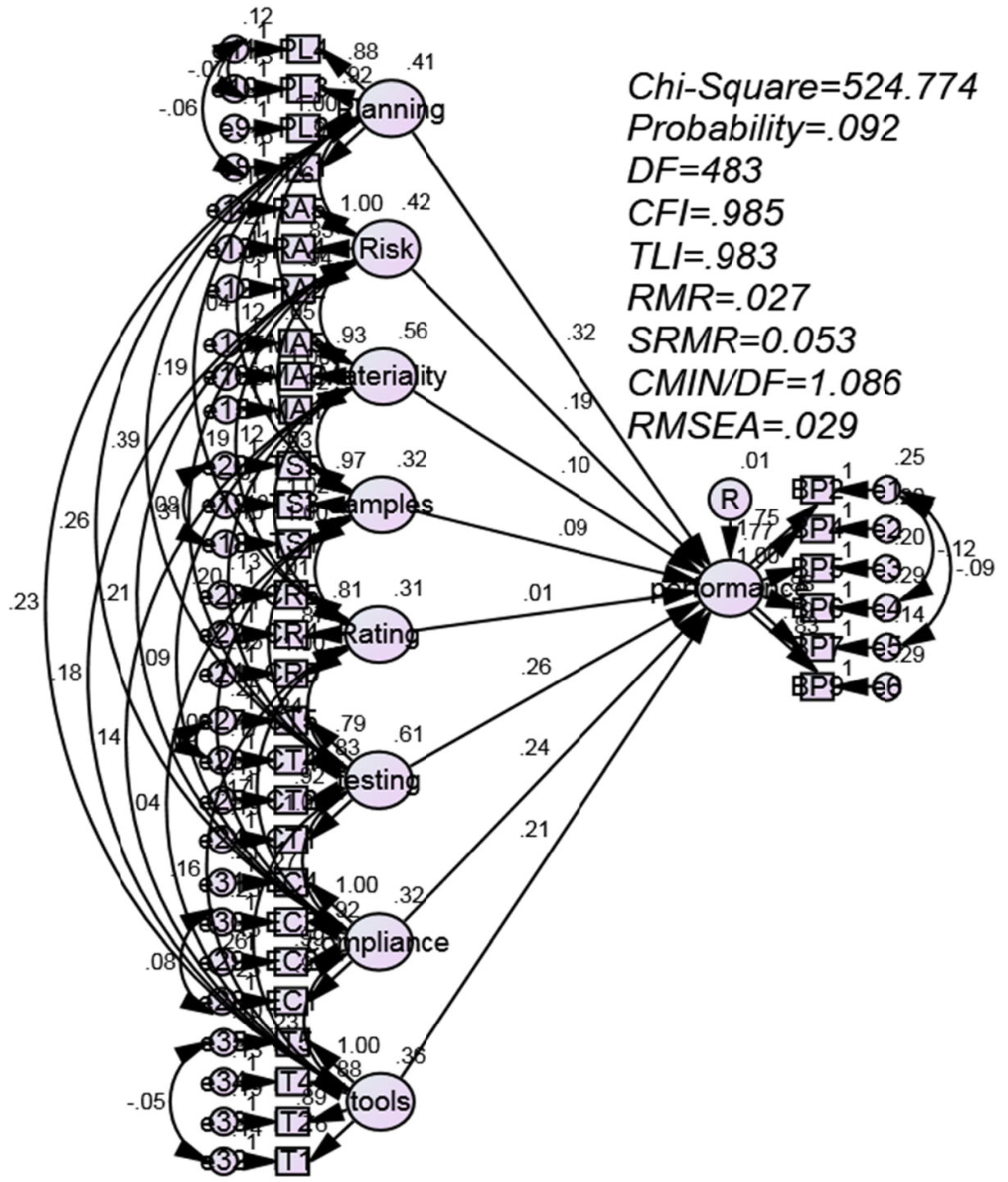

Figure 1. Structural model estimation

Figure 1 presents the factor loadings for items in the measurement model for the Impact External Shari'ah Audit on Efficiency of Islamic Banks Performance.

\subsection{Hypothesis Testing}

The direct effect represents the effect from exogenous construct endogenous construct, Figure (1) and Table (3), shows that the hypotheses test, in determining the significance of each path coefficient, estimate of regression weight, standard error of regression weight, and critical ratio for regression weight, were used.

Table (3) demonstrated planning construct has a significant positive and direct impact on efficiency of Islamic banks performance $(\beta=0.323, C . R=4.337 ; P<0.001)$ indicating that $\mathrm{H} 1$ is accepted.

Similarly, risk assessment construct has a significant positive and direct impact on efficiency of Islamic banks 
performance $(\beta=0.188, C . R=3.523 ; P<0.001)$ indicating that $\mathrm{H}_{2}$ is accepted.

Also materiality assessment construct has a significant positive and direct impact on efficiency of Islamic banks performance $(\beta=0.102, C . R=2.895 ; P<0.01)$ indicating that $\mathrm{H}_{3}$ is accepted.

And sampling construct has a significant positive and direct impact on efficiency of Islamic banks performance $(\beta=0.087, C . R=2.042 ; P<0.05)$ indicating that $\mathrm{H}_{4}$ is accepted.

But, internal control - assessment construct has an insignificant positive and direct impact on efficiency of Islamic banks performance $(\beta=0.010, C . R=0.185 ; P>0.05)$ indicating that $\mathrm{H}_{5}$ is unaccepted.

While, internal controls-testing construct has a significant positive and direct impact on efficiency of Islamic banks performance $(\beta=0.255, C . R=4.305 ; P<0.001)$ indicating that $\mathrm{H}_{6}$ is accepted.

And evaluation of observations and Shari'ah non-compliances construct has a significant positive and direct impact on efficiency of Islamic banks performance $(\beta=0.238, C . R=2.819 ; P<0.01)$ indicating that $\mathrm{H}_{7}$ is accepted.

Similarly, using the work of relevant internal functions construct has a significant positive and direct impact on efficiency of Islamic banks performance $(\beta=0.207, C . R=3.469 ; P<0.001)$ indicating that $\mathrm{H}_{8}$ is accepted.

Table 3. Hypotheses testing result

\begin{tabular}{llllll}
\hline Hypotheses & Estimate & S.E. & C.R. & P-Value & Result \\
\hline $\mathbf{H}_{\mathbf{1}}$ & 0.323 & 0.075 & 4.337 & $* * *$ & Supported \\
$\mathbf{H}_{\mathbf{2}}$ & 0.188 & 0.053 & 3.523 & $* * *$ & Supported \\
$\mathbf{H}_{3}$ & 0.102 & 0.035 & 2.895 & 0.004 & Supported \\
$\mathbf{H}_{\mathbf{4}}$ & 0.087 & 0.043 & 2.042 & 0.041 & Supported \\
$\mathbf{H}_{5}$ & 0.010 & 0.054 & 0.185 & 0.853 & Not Supported \\
$\mathbf{H}_{\mathbf{6}}$ & 0.255 & 0.059 & 4.305 & $* * *$ & Supported \\
$\mathbf{H}_{7}$ & 0.238 & 0.085 & 2.819 & 0.005 & Supported \\
$\mathbf{H}_{\mathbf{8}}$ & 0.207 & 0.060 & 3.469 & $* * *$ & Supported \\
\hline
\end{tabular}

Note. $* * *$ indicate a highly significant at $<0.001$.

\section{Discussion of Findings}

Model modification for this study was necessary, since the structural equation model fit indices has not been satisfactory. From perspective of auditors and employees in Islamic banks, this suggests effect of external Shariah audit on efficiency of Islamic banks performance. These imply that was role of planning, risk assessment, materiality assessment, sampling, internal controls - testing, evaluation of observations and Shari'ah non-compliances, using the work of relevant internal functions leads to better efficiency performance in Islamic banks, except in the case of Internal Control - assessment not show this role.

\section{Conclusion and Future Research}

This study has revealed that external Shari'ah audit significantly affect the efficiency of Islamic banks performance. We also found that, seven construct significantly affect the Islamic banks performance, but not in one case it is recommended to include a mediating variable such as corporate governance or ownership structure to explain the other variables. In this study did not include at study sample any mediating variable as corporate governance or ownership as feature to insight of the indirect relationship.

Results of this study will be useful for the external and internal auditors for Islamic banks performance development through enhancement of method Shari'ah audit in the Islamic banking sector.

\section{References}

AAOIFI, A. (2010). Accounting, auditing and governance standards for Islamic financial institutions. Manama, Bahrain: AAOIFI.

AAOIFI, A. (2015). Accounting, auditing and governance standards for Islamic financial institutions. Manama, Bahrain: AAOIFI.

Al-Khulaifi, R. M. (2004). External Shari'ah Audit Strategy Concepts and Mechanism of Action. Research Paper presented to the Fourth Conference of Shari'ah Supervisors in Islamic Financial Institutions Accounting and Auditing Organization for Islamic Financial Institutions in the Kingdom of Bahrain. 
Arwani, A. (2018). Issues and Challenges of Shariah Auditing in Iislamic Financial Institution and Corporate Governance Compliance. Media Riset Akuntansi, Auditing \& Informasi, 18(2), 169-186. https://doi.org/10.25105/mraai.v18i2.3008

Bashir, A. H. M. (2001). Assessing the performance of Islamic banks: Some evidence from the Middle East. Topics in Middle Eastern and North African Economies, 3.

Berthoud, R., \& Gershuny, J. (Eds.). (2000). Seven years in the lives of British families: Evidence on the dynamics of social change from the British Household Panel Survey. Policy Press.

Chapman, R. J. (1998). The effectiveness of working group risk identification and assessment techniques. $\begin{array}{lllll}\text { International Journal of Project } & \text { Management, } & 16(6), & 333-343 .\end{array}$ https://doi.org/10.1016/S0263-7863(98)00015-5

Chau, P. Y., \& Hu, P. J. H. (2001). Information technology acceptance by individual professionals: A model $\begin{array}{lllll}\text { comparison } & \text { approach. } & \text { Decision } & \text { 32iences, } & \text { 69-719. }\end{array}$ https://doi.org/10.1111/j.1540-5915.2001.tb00978.x

Cronbach, L. J. (1971). Test Validation. In R. L. Thorndike (Ed.). Educational Measurement (2nd ed.). Washington, D. C: American Council on Education.

George, D. \& Mallery, M. (2010). Using SPSS for Windows step by step: a simple guide and reference. Boston, MA: Allyn \& Bacon.

George, D., \& Mallery, P. (2014). IBM SPSS statistics 21 step by step: A simple guide and reference (13th ed.). Boston, MA: Pearson.

Ginena, K., \& Hamid, A. (2015). Foundations of Shari'ah governance of Islamic banks. John Wiley \& Sons.

Hair, J. F. J., Black, W. C., Babin, B. J., \& Anderson, R. E. (2010). Multivariate Data Analysis (7th ed.). Prentice Hall, New Jersey.

Hair, J. F., Anderson, R. L., \& Tatham, W. C. (1998). Multivariate Data Analysis with Reading. NJ: Prentice-Hall.

Haniffa, R. (2010). Auditing Islamic financial institutions. Islamic Finance: Instruments and Markets (QFinance), Bloomsbury, London.

Haniffa, R., Hudaib, M., \& Mirza, A. M. (2004). Accounting Policy Choice within the Shariah Islamiiah Framework. Discussion Papers in Accountancy and Finance, SOBE, University of Exeter, 2, 4-19.

Hooper, D., Coughlan, J., \& Mullen, M. (2008). Structural equation modelling: Guidelines for determining model fit. Electronic Journal of Business Research Methods, 6(1), 53-60.

Hu, L. T., \& Bentler, P. M. (1999). Cutoff criteria for fit indexes in covariance structure analysis: Conventional criteria versus new alternatives. Structural equation modeling: A multidisciplinary journal, 6(1), 1-55. https://doi.org/10.1080/10705519909540118

Khalid, A. A., \& Sarea, A. M. (2018) Independence and Effectiveness of Internal Shariah Audit: An Islamic Agency Theory. Proceeding of the 5th International Conference on Management and Muamalah.

Khalid, S., \& Amjad, S. (2012). Risk Management Practices in Islamic banks of Pakistan. The Journal of Risk Finance, 13(2), 148-159. https://doi.org/10.1108/15265941211203198

Kline, R. B. (2005). Principles and practice of structural equation modeling. New York: Guilford.

Kline, R. B. (2010). Principles and Practice of Structural Equation Modeling. Series Editor's Note by Todd D. Little.

Kurd, A. A. (2010). Islamic banks objectives and services. Electronic encyclopaedia, 3. Egypt: Azhar University.

Mohammad, Z. (2009). Activating the Role of Supervision and Shariah Auditing in Islamic Banks and Institutions. Conference of Islamic Banks Reality and Hope, Dubai.

Qasim, Y., Mohamad, Y., \& Ibrahim, N. (2017). Measuring the performance of Jordanian Islamic banks'. Journal of Public Administration and Governance, 7(1), 25-47. https://doi.org/10.5296/jpag.v7i1.10575

Rahman, A. R. A. (2011). Enhancing the Integrity of Islamic Financial Institutions in Malaysia: The Case for Shariah Audit Framework. ISRA International Journal of Islamic Finance, 3(1), 135-147.

Rahman, R. A., Alsmady, A., Ibrahim, Z., \& Muhammad, A. D. (2014). Risk management practices in Islamic 
banking institutions: A comparative study between Malaysia and Jordan. Journal of Applied Business Research, 30(5), 1295. https://doi.org/10.19030/jabr.v30i5.8786

Shafii, Z., Salleh, S., \& Shahwan, S. H. (2010). Management of Shariah non-compliance audit risk in the Islamic financial institutions via the development of Shariah compliance audit framework and Shariah audit programme. Kyoto Bulletin of Islamic Area Studies, 3(2), 3-16.

Shahul, H. M. I., \& Yaya, R. (2005). The emerging issues on the objectives and characteristics of islamic accounting for Islamic business organizations. Malaysian Accounting Review, 4(1).

Sultana, R., \& Haque, M. E. (2011). Evaluation of Internal Control Structure: Evidence from Six Listed Banks in Bangladesh. ASA University Review, 5(1), 69-81

Swartz, N. P. (2013). Risk management in Islamic banking. African Journal of Business Management, 7(37), 3799-3809. https://doi.org/10.5897/AJBM12.741

Tabachnick, B. G., Fidell, L. S., \& Ullman, J. B. (2007). Using multivariate statistics (Vol. 5). Boston, MA: Pearson.

\section{Copyrights}

Copyright for this article is retained by the author(s), with first publication rights granted to the journal.

This is an open-access article distributed under the terms and conditions of the Creative Commons Attribution license (http://creativecommons.org/licenses/by/4.0/). 